\section{US-Soviet dispute persists over alleged psychiatric practices}

Washington \& London

US officials have expressed surprise and consternation over remarks made by Soviet Minister of Health Evgenii Chazov about US attitudes towards Soviet psychiatry reported in last week's Nature (see 330, 595; 1987). In a recent speech, Chazov said the US Department of Health and Human Services had rejected an offer to form a joint commission to investigate alleged misuse of psychiatry because US psychiatrists were not interested in Soviet psychiatry. But a US Health Department official emphasized that only the specific commission proposed by Chazov was rejected, and that the United States is committed to resolving issues that have prevented scientific exchanges in psychiatry between the two countries.

The US government refuses to allow formal scientific exchanges between US and Soviet psychiatrists to take place because of concern about Soviet psychiatric practices. Particularly upsetting to the US government are practices at the Serbskii Institute of Forensic Psychiatry. Dr Aleksandr Snezhnevskii, former head of the institute, has described all mental illness as a form of schizophrenia, and political dissent as a form of "creeping schizophrenia", a condition unknown to psychiatrists elsewhere.

In 1983, the All Union Society of Psychiatrists and Neuropathologists of the Soviet Union resigned from the World Psychiatric Association (WPA) as WPA

\section{Supercomputer compromise still unsettled}

\section{Bangalore \& Washington}

A year-long controversy over the supply of a supercomputer to India from the United States has ended in compromise. Although the terms of the agreement are very general, it seems that India will be offered a Cray XMP-14 supercomputer, rather than the more advanced XMP-24 model which had been requested. But many Indian scientists, concerned that the Cray is soon to go out of production, are backing the purchase of a supercomputer from Control Data Corporation.

According to diplomatic sources in Washington, during the recent visit to the United States of the Indian Prime Minister, Mr Rajiv Gandhi, the United States had assured him of the upgrading of the Cray XMP-14 into the XMP-24 in the foreseeable future. The United States had also agreed to transfer the latest computer software to India.

Meanwhile, Mr Bruce Smart, the United States under secretary, has revealed that India has expressed its interest in another doning abusive psychiatric practices. The American Psychiatric Association (APA) will not allow official contact with the All Union Society unless it includes "the opportunity for discussion of abuse of psychiatry" in the Soviet Union, making formal collaboration effectively impossible. Exchanges between individuals may still occur.

Lately, the Soviet media - notably the Communist youth paper, Komsomolskaya Pravda - have begun to investigate cases of workers compulsorily hospitalized in psychiatric units, allegedly for being "troublemakers". this has given the Soviet health establishment a renewed interest in showing that psychiatric abuses do not occur. In April, Health Minister Chazov approached Ambassador Richard Schifter, US assistant secretary of state for human rights and humanitarian affairs, asking Schifter to visit psychiatric hospitals in the Soviet Union. But Schifter declined, suggesting instead that a delegation from the APA go.

In August, Ellen Mercer, director of APA's office of international affairs, wrote to the Soviet embassy in Washington, requesting a meeting to discuss a visit by an APA panel. Mercer says the embassy has yet to reply. She says APA's proposed delegation would resolve the question of abuses. The APA asks that a delegation be allowed to visit patients of its choosing, to examine patients in the

supercomputer. Control Data Corporation has reached an agreement with India and the State Department to ship up to one single processor from its latest generation of supercomputers including the $E$ series models 1032, 1064, 1096 and 1128 which have memory sizes of 64 or 27 megawords, or the ETA/10T or ETA/10Q models made by ETA Systems Inc. The Bangalore-based Indian Institute of Science, which wants a supercomputer to aid in its monsoon forecasting research programme, may well choose a Control Data Corporation model in preference to the Cray model.

Many well-informed Indians feel that the US willingness to export the Cray is due not to generosity but to the fact that there are no buyers for the XMP series as a consequence of the Cray Corporation's decision to scrap production of the series. And many users of this series, including the British Department of Energy, are now worried about future servicing and maintenance of their system.

Radhakrishna Rao \& Elizabeth Bragunier was preparing to expel the society for con- hospitals where they are treated and to have family members present during examinations. In addition, the delegation seeks to have its own interpreters, and to have patients taken off their "medications or other treatments designed to alter their behaviour" for the period of the delegation's visit.

One likely reason for the Soviet's silence on the APA's offer is animosity towards the organization. It played a major role in factors leading to the Soviet Union's withdrawal from the WPA.

The Soviet Union approached the Department of Health and Human Services to see if exchanges in psychiatric research could be worked out under the terms of the bilateral health agreement currently in place between the two countries. But following consultation with the State Department the request was refused because of the unresolved issue of abuses, especially at the Serbskii Institute. Harold Thompson, deputy director of the office of international health, says permitting exchanges would have the effect of giving official US government approval for Soviet psychiatry. That, he argues, should be the job of the private sector, in this case the APA.

With formal channels unwilling or unable to provide the sort of delegation sought by the Soviet Union, Chazov has tried yet another route. He is co-chairman of the International Physicians Movement against Nuclear War, for which role he shared the Nobel peace prize with American Bernard Lown in 1985. Chazov suggested to Lown that a group of distinguished US psychiatrists could visit the Soviet Union. Lown passed on the request to Lester Grinspoon, associate professor of psychiatry at Harvard Medical School, who wrote to Chazov on 29 October making essentially the same proposal as the APA. Grinspoon says his group would not represent APA, and thus might enable the Soviet Union to save face by not having to deal with the APA. But he also reminded Chazov that any report his group might write would have more influence if it were supported by the APA. Grinspoon proposes publishing both his delegation's report and a Soviet response to it.

Grinspoon has also not yet received a response. The subject of Soviet psychiatric practices came up at the summit meeting between President Ronald Reagan and General Secretary Mikhail Gorbachev earlier this month in Washington. Both governments reiterated their interest in the issue, but the United States continues to maintain that the APA should conduct such an investigation. Grinspoon hopes that his private initiative will ultimately be acceptable to all sides, and says he expects an answer from Chazov shortly.

Joseph Palca \& Vera Rich 